\title{
Analisa Blazer menggunakan Pola Dankaerts Ditinjau dari Faktor Kenyamanan pada Ukuran M, L dan XL
}

\author{
Annissa Fitriani, Nurul Aini*, Esin Sintawati \\ Universitas Negeri Malang, Jl. Semarang No. 5 Malang, Jawa Timur, Indonesia \\ *Penulis korespondensi, Surel: nurul.aini.ft@um.ac.id
}

Paper received: 03-03-2021; revised: 12-03-2021; accepted: 22-03-2021

\begin{abstract}
Abstrak
Blazer sekarang digunakan dalam acara resmi atau tidak resmi. Wanita menggunakan blazer tidak hanya dari modelnya saja tetapi juga dari kenyamanannya. Faktor kenyamanan Blazer dipengaruhi oleh banyak faktor, salah satunya yaitu pembuatan pola. Terdapat beberapa metode pola, salah satunya yaitu metode pola Dankaerts. Penelitian ini bertujuan untuk mengetahui faktor kenyamanan pada blazer menggunakan pola Dankaerts ukuran M, L dan XL ditinjau dari dua sudut pandang yaitu faktor kenyamanan statis dan faktor kenyamanan kinetis. Metode penelitian ini adalah deskriptif dengan pendekatan kuantitatif. Instrumen penelitian ini berupa angket dan lembar pengamatan yang diberikan kepada tiga responden dan tiga panelis. Lembar pengamatan terdiri dari dua bagian variabel yaitu kenyamanan statis dan kenyamanan kinetis. Faktor kenyamanan statis terdapat 17 indikator sedangkan faktor kenyamanan kinetis terdapat 3 indikator. Teknik pengumpulan data dilakukan dengan cara observasi dan angket. Teknik analisis data yang digunakan adalah analisis persentase. Penelitian tentang faktor kenyamanan blazer menggunakan pola Dankaerts pada ukuran M faktor kenyamanan statis mendapatkan persentase nyaman sebanyak 75,56 persen sedangkan faktor kenyamanan kinetis kategori nyaman sebanyak 78,94 persen. Untuk faktor kenyamanan blazer ukuran L ditinjau dari faktor kenyamanan statis persentase nyaman adalah 76,11 persen sedangkan faktor kenyamanan kinetis kategori nyaman sebanyak 87,34 persen. Dan faktor kenyamanan blazer ukuran XL faktor kenyamanan statis memperoleh persentase nyaman sejumlah 89,58 persen sedangkan faktor kenyamanan kinetis kategori nyaman sejumlah 81,08 persen. Hasil penelitian menunjukkan bahwa tingkat kesesuaian faktor kenyamanan tertinggi pada blazer menggunakan pola Dankaerts ditinjau dari faktor kenyamanan statis adalah ukuran XL dan faktor kenyamanan kinetis adalah ukuran L. Ini dapat disimpulkan bahwa pola Dankaerts sesuai dan nyaman pada wanita bertubuh gemuk atau ukuran besar. Disarankan: (1) bagi peneliti sejenis untuk mengembangkan dari berbagai aspek lain; (2) bagi guru dapat dijadikan sebagai masukan untuk pemilihan pola dalam pembuatan blazer; (3) bagi pelaku bisnis (pembuat pola atau produksi busana) lebih diperhatikan dalam proses pengambilan ukuran dan pembuatan pola.
\end{abstract}

Kata kunci: blazer; pola Dankaerts; kenyamanan

\section{Pendahuluan}

Seiring dengan perkembangan jaman, berbusana tidak hanya berfungsi untuk melindungi tubuh dari cuaca dan gigitan serangga namun juga berfungsi untuk menambah keindahan sipemakai. Pada umumnya busana dikelompokkan menjadi dua bagian yaitu busana dalam dan busana luar. Menurut Ernawati, et al., (2008) "busana dalam dibagi menjadi dua yaitu busana yang langsung menutupi kulit dan busana yang tidak menutupi kulit, sedangkan busana luar ialah busana yang dipakai diatas busana dalam". Salah satu busana yang sering terlihat di kehidupan sehari-hari adalah busana kerja, karena pada zaman dahulu pekerjaan rata-rata dilakukan oleh kaum pria, sedangkan jaman sekarang kaum wanita juga banyak yang memiliki pekerjaaan. Busana kerja mempunyai kriteria yang berbeda sesuai dengan pekerjaannya, contohnya: guru, pekerja bangunan, dokter, montir dan sebagainya (Rahayu, 2008). 
Busana kerja pria dan wanita memiliki perbedaan yaitu dalam pemilihan model dan bahan yang digunakan. Pakaian kerja pria pada umumnya jas, kemeja dan celana, sedangkan untuk wanita bisa menggunakan blus, rok/celana, jas dan blazer. Jas/blazer pada umumnya pakaian kerja yang bisa digunakan oleh pria maupun wanita untuk menambah kesan formal. Namun, pekerja kantor wanita lebih sering menggunakan blazer daripada jas, karena pemakaian blazer bisa mengikuti bentuk tubuh pemakai dan terlihat lebih feminim. Menurut Fakhiroh (2013), "blazer merupakan busana berbentuk semi jas yang dapat dikenakan pada berbagai macam kesempatan, baik formal maupun non formal tergantung bahan dan desainnya".

Teknik pembuatan blazer akan terlihat lebih bagus apabila menggunakan teknik tailoring, namun pada umumnya pembuatan blazer menggunakan teknik semi tailoring. Teknik semi tailoring merupakan teknik jahit pada bagian tengah muka TM dan bagian tengah belakang (TB) menggunakan furing sedangkan untuk bagian lengan tidak menggunakan furing (Lestari, 2012). Untuk mendapatkan kualitas blazer yang baik memerlukan beberapa tahapan yang harus dilakukan, antara lain memilih bahan, mengambil ukuran, membuat pola blazer dan lain sebagainya. Dari hasil akhir pembuatan blazer sering ditemukan masalah, salah satunya yaitu saat digunakan merasa tidak nyaman, faktor itu bisa disebabkan terjadinya kesalahan saat proses pembuatan. Ada banyak faktor untuk menghasilkan blazer yang nyaman salah satunya adalah teknik pembuatan pola.

Pola yang digunakan dalam penelitian ini adalah pola Dankaerts, alasan mengapa peneliti mengkaji pola Dankaerts karena teknik pola dasar metode Dankaerts belum pernah dianalisis terutama dalam pembuatan blazer, penelitian sebelumnya yang berkaitan dengan pola Dankaerts yaitu tentang Penyesuaian Pola Dasar Sistem Dankaerts Pada Wanita Bertubuh Gemuk Pendek pada tahun 2015. Alasan pendukung lainnya yaitu dalam dunia pendidikan salah satunya di SMK Negeri 3 Malang pola Dankaerts digunakan sebagai referensi mata pelajaran pembuatan pola khususnya pola blazer dan ingin mengetahui faktor kenyamanan pola Dankaerts apabila diterapkan pada blazer untuk ukuran M, L dan XL.

\section{Metode}

Penelitian ini merupakan penelitian deskriptif dengan pendekatan kuantitatif (Suharsono, 2018). Populasi dalam penelitian ini adalah populasi responden dan panelis, populasi responden yaitu mahasiswa S1 Pendidikan Tata Busana Universitas Negeri Malang angkatan 2015 Offering A yang memiliki ukuran badan sesuai dengan ukuran standar M, L dan XL. Populasi panelis adalah dosen tata busana Universitas Negeri Malang yang menguasai materi mengenai blazer.

Sampel yang digunakan pada penelitian ini adalah sampel jenuh. Menurut Sugiyono (2017) sampel jenuh atau istilah lainnya sensus adalah teknik penentuan sampel apabila semua anggota populasi yang ada digunakan sebagai sampel. Instrumen yang digunakan dalam penelitian ini berupa lembar pengamatan yang berisi kriteria penilaian pedoman yang dijabarkan dalam instrumen sesuai dengan aspek yang akan dinilai (Arikunto, 2010). Penggunaan lembar pengamatan dibuat dalam bentuk checklist $(\sqrt{ })$ berdasarkan tiga kategori (nyaman, kurang nyaman dan tidak nyaman). Uji instrumen penelitian ini menggunakan uji validitas konstruk pendapat para ahli (Sugiyono, 2017). 
Teknik pengumpulan data yang digunakan yaitu observasi dan angket. Teknik analisis data menggunakan analisis persentase dengan berbagai tahapan diantaranya (1) memberikan skor (2) tabulasi data (3) uji statistika (4) interpretasi data. Rumus yang digunakan adalah

$$
P=f / n \times 100 \%
$$

\section{Keterangan:}

$\mathrm{P}=$ Persentase faktor kenyamanan

$\mathrm{f}=$ frekuensi jumlah nyaman, kurang nyaman dan tidak nyaman

$\mathrm{n}=$ jumlah keseluruhan kriteria

\section{Hasil dan Pembahasan}

Penelitian ini bertujuan untuk mengetahui faktor kenyamanan blazer ditinjau dari dua faktor, yaitu faktor kenyamanan statis dan kinetis menggunakan pola Dankaerts dengan ukuran M, L dan XL. Pada penelitian ini faktor kenyamanan statis berjumlah tujuh belas kriteria dan faktor kenyamanan kinetis berjumlah tujuh kriteria.

\subsection{Analisa Blazer Ditinjau dari Faktor Kenyamanan Statis}

Faktor kenyamanan statis adalah faktor kenyamanan yang dinilai atau dilihat saat posisi diam.

\subsubsection{Ukuran M}

Faktor kenyamanan blazer ukuran M memperoleh hasil fitting nyaman dengan hasil persentase kategori nyaman sebanyak 75,56 \%, kategori kurang nyaman sebanyak 23,70 \%, kategori tidak nyaman sebanyak 0,74 \%. Saat proses fitting banyak hal yang perlu diperhatikan. Faktor yang bisa menciptakan kenyamanan pada busana salah satunya yaitu posisi saat pengambilan ukuran, menurut Hidayah dan Yasnidawati (2019) banyak hal yang perlu diperhatikan dalam pengambilan ukuran diantaranya yaitu pakaian yang digunakan sebaiknya pas body, sikap model berdiri tegap dan memberikan tanda pada bagian-bagian lingkar badan, lingkar pinggang dan lingkar panggul. Pada ukuran ini dapat diinterpretasikan pada kategori nyaman karena sebagian besar ketepatan fitting factor ukuran M sudah sesuai dengan kriteria faktor kenyamanan statis dan blazer terlihat menarik pada tubuh model.

\subsubsection{Ukuran $L$}

Hasil penelitian dengan persentase kategori nyaman sebanyak 76,11\%, kategori kurang nyaman sebanyak 22,38 \%, kategori tidak nyaman sebanyak 1,49\%. Ukuran ini termasuk dalam kategori nyaman dikarenakan beberapa kriteria yang terdapat pada ukuran ini sudah tepat salah satunya yaitu posisi lingkar pinggang. Hal tersebut sejalan dengan pernyataan Irmayanti (2017) kurangnya titik pas (fitting factor) suatu busana yaitu kedudukan garis lingkar pinggang yang tidak tepat. Berdasarkan hasil ukuran L dapat diinterpretasikan dalam kategori nyaman dikarenakan kriteria yang terdapat pada faktor kenyamanan statis sudah baik dan memiliki tingkat ketepatan yang baik.

\subsubsection{Ukuran XL}


Persentase dari hasil penilaian, dapat diketahui persentase hasil pengamatan secara keseluruhan yaitu kategori nyaman sebanyak 89,58 \%, kategori kurang nyaman sebanyak 9,72 \%, kategori tidak nyaman sebanyak 0,69 \%. Ukuran ini memperoleh hasil nyaman Hal ini dibuktikan dari keseluruhan kriteria faktor kenyamanan statis dengan jumlah 17 mendapatkan hasil yang tepat (nyaman).

\subsection{Analisa Blazer Ditinjau dari Faktor Kenyamanan Kinetis}

Faktor kenyamanan kinetis adalah faktor kenyamanan yang dapat dilihat saat beraktivitas.

\subsubsection{Ukuran $M$}

Kenyamanan blazer ukuran M memperoleh hasil nyaman dengan persentase kategori nyaman sebanyak 78,94\%, kategori kurang nyaman sebanyak $21,05 \%$, kategori tidak nyaman sebanyak $0 \%$. Ketidaknyamanan pada suatu busana dapat dilihat pada saat pakaian tersebut dikenakan. Salah satunya yaitu pada saat blazer digunakan dalam kondisi duduk dengan posisi kancing terpasang. Menurut Vorensia (2019) duduk di kursi dapat dikatakan nyaman apabila letak garis pinggang tepat pada garis pinggang, mudah saat digunakan untuk duduk dikursi dan tidak terdapat bagian yang tertarik. Ukuran ini dapat diinterpretasikan dalam kategori nyaman dikarenakan dari hasil yang telah diperoleh sebagian besar sesuai dengan kriteria faktor kenyamanan kinetis dan cukup atau pas pada tubuh model.

\subsubsection{Ukuran $L$}

Mengenai faktor kenyamanan kinetis pada blazer ukuran L menggunakan pola Dankaerts, dapat diketahui persentase hasil pengamatan secara keseluruhan yaitu kategori nyaman sebanyak $87,34 \%$, kategori kurang nyaman sebanyak $12,65 \%$, kategori tidak nyaman sebanyak $0 \%$. Ukuran L mendapatkan hasil yang nyaman. Hal ini didukung oleh pendapat Irmayanti (2017) kurangnya kenyamanan dalam pemakaian suatu busana yaitu terjadinya kerut dan gelombang pada busana. Berdasarkan hasil ukuran ini dapat diinterpretasikan dalam kategori nyaman dikarenakan kriteria yang terdapat pada faktor kenyamanan kinetis sudah tepat dengan memiliki tingkat kenyamanan yang baik sehingga nyaman saat digunakan untuk bergerak.

\subsubsection{Ukuran XL}

Hasil penelitian dapat diketahui ukuran ini memperoleh hasil yang nyaman dengan persentase kategori nyaman sebanyak 81,08\%, kategori kurang nyaman sebanyak 16,21 \%, kategori tidak nyaman sebanyak 2,66 \%. Dalam faktor kenyamanan kinetis dapat diketahui nyaman atau tidaknya busana apabila saat dikenakan untuk bergerak, menurut Vorensia (2019) kondisi bergerak dalam kondisi tangan ditekuk dapat dikatakan nyaman apabila mudah digunakan untuk bergerak dan tidak terdapat bagian yang tertarik. Ukuran XL termasuk dalam interpretasi kategori nyaman, hal tersebut dapat dibuktikan pada ukuran ini memiliki ketepatan yang baik dan sesuai dengan letak atau garis pada tubuh model sehingga terlihat bagus dan nyaman saat digunakan. 
Berikut adalah hasil keseluruhan dari faktor kenyamanan statis dan kinetis pada blazer menggunakan pola Dankaerts yang disajikan dalam bentuk diagram batang pada ukuran M, L dan XL.

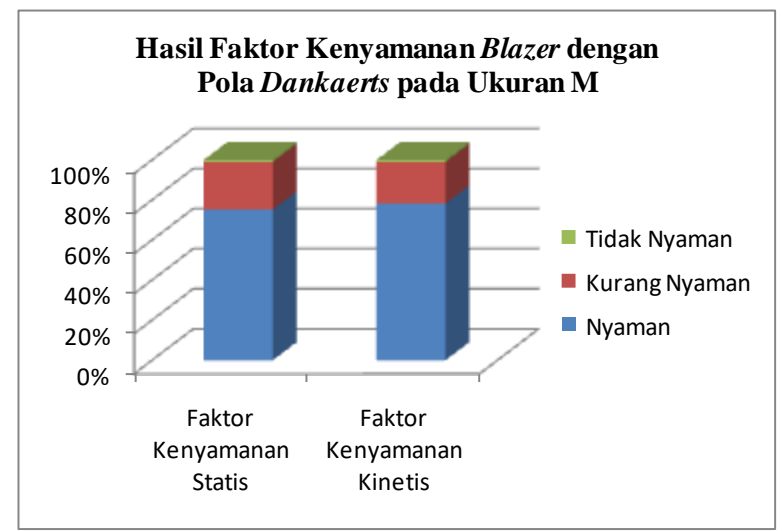

Gambar 1. Diagram Batang Faktor Kenyamanan Blazer dengan Pola Dankaerts Ukuran M

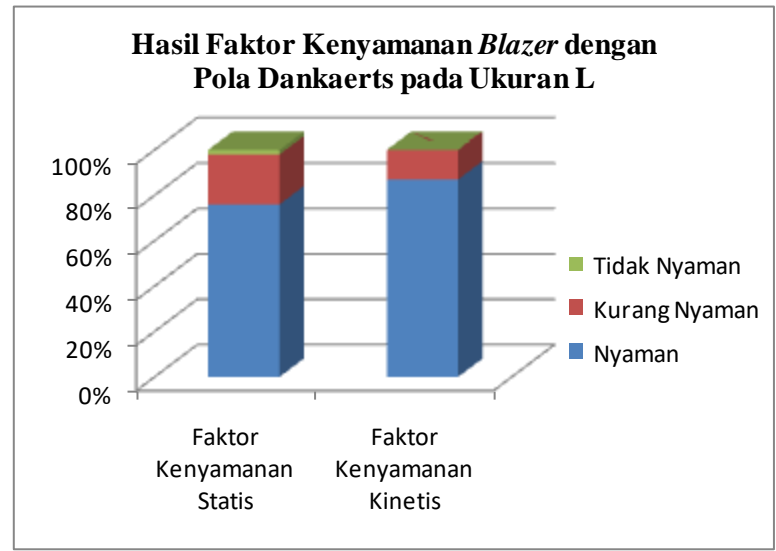

Gambar 2. Diagram Batang Faktor Kenyamanan Blazer dengan Pola Dankaerts Ukuran L

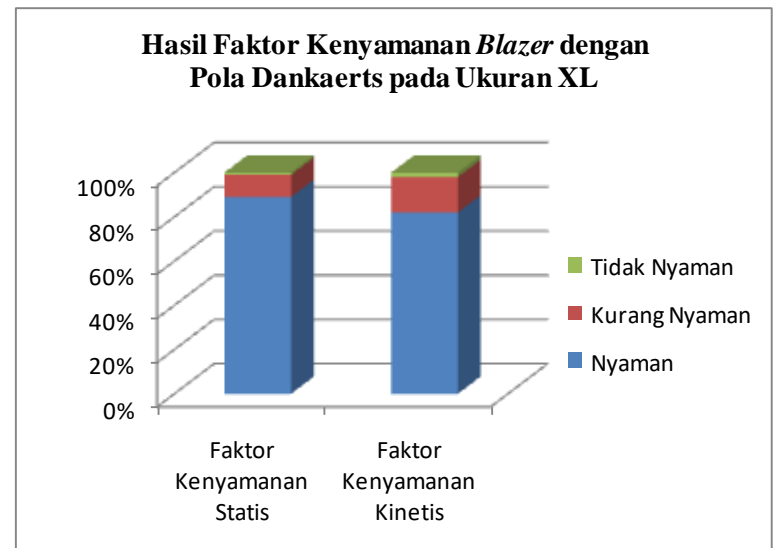

Gambar 3. Diagram Batang Faktor Kenyamanan Blazer dengan Pola Dankaerts Ukuran XL

Secara keseluruhan jika dilihat dari diagram diatas faktor kenyamanan statis ukuran XL mendapatkan hasil kategori nyaman yang paling tinggi sedangkan faktor kenyamanan kinetis hasil yang mendapatkan hasil tertinggi adalah ukuran L. Hal ini sesuai dengan referensi 
penelitian dari Hasanah Nursanti (2015) bahwa pola dasar Dankaerts sesuai pada wanita bertubuh gemuk, sehingga dapat dibuktikan bahwa pola Dankaerts tepat dan nyaman untuk ukuran besar.

\section{Simpulan}

\subsection{Simpulan}

Berdasarkan hasil penelitian dan pembahasan mengenai analisa blazer menggunakan pola Dankaerts ditinjau dari faktor kenyamanan statis ukuran M, L dan XL termasuk dalam kategori nyaman. Kelebihan pada faktor kenyamanan statis ukuran XL memiliki ketepatan fitting factor baik dan sesuai dengan letak atau garis pada tubuh model sehingga terlihat bagus dan nyaman saat digunakan. Sedangkan kekurangannya ada beberapa fitting factor pada ukuran M dan L yang kurang tepat, hal tersebut bisa terjadi karena kurangnya ketepatan atau ketelitian pada saat pengambilan ukuran dan pembuatan pola blazer. Dilihat dari hasil point yang diperoleh faktor kenyamanan statis ukuran XL mendapatkan point kategori nyaman yang paling tinggi, hal ini sesuai dengan referensi bahwa pola Dankaerts sesuai dengan ukuran gemuk atau besar.

Faktor kenyamanan blazer ditinjau dari faktor kenyamanan kinetis ukuran M, L dan XL ditinjau dari hasil keseluruhan termasuk dalam kategori nyaman. Kelebihan pada faktor kenyamanan kinetis ukuran L memperoleh hasil tepat dan nyaman saat digunakan untuk bergerak dan tidak merasakan kesakitan. Kekurangannya pada ukuran M dan XL terdapat beberapa kriteria yang kurang nyaman sehingga saat blazer digunakan model merasa kesakitan dan kurang leluasa digunakan untuk bergerak. Dari hasil point yang diperoleh faktor kenyamanan kinetis ukuran L mendapatkan point kategori nyaman yang paling tinggi, hal ini dibuktikan bahwa pola Dankaerts sesuai untuk ukuran gemuk atau besar.

\subsection{Saran}

Berdasarkan kesimpulan, berikut saran yang dapat disampaikan oleh peneliti: 1) Bagi peneliti sejenis, penelitian ini dapat disempurnakan lagi dengan cara mengembangkan berbagai aspek lain dengan cara menggunakan metode pola yang berbeda dan ukuran yang berbeda. 2) Bagi guru terutama guru SMKN 3 Malang diharapkan dapat dijadikan sebagai masukan khususnya untuk pemilihan pola dalam pembuatan blazer dengan menggunakan pola Dankaerts karena berdasarkan hasil penelitian pola Dankaerts sesuai untuk ukuran besar atau tubuh besar. 3) Bagi pelaku bisnis busana (pembuat pola atau produksi busana) sebaiknya dalam menggunakan pola Dankaerts lebih diperhatikan pada saat pembuatan pola atau membentuk garis pola karena dalam pembuatan pola Dankaerts memiliki cara yang berbeda dengan sistem pola lainnya.

\section{Daftar Rujukan}

Arikunto, S. (2010). Prosedur Penelitian Suatu Pendekatan Praktik. Jakarta: Rineka Cipta.

Ernawati, E., et al. (2008). Tata Busana Jilid 2. Jakarta: Direktorat Pembinaan Sekolah Menengah Kejuruan.

Fakhiroh, Z. (2013). Studi tentang teknik pembuatan blazer di Jaber Tailor untuk ukuran S, M, L, XS, dan XXL (Doctoral dissertation, Universitas Negeri Malang).

Hasanah, N., Yasnidawati, Y., \& Nelmira, W. (2015). Penyesuaian Pola Dasar Sistem Danckaerts pada Wanita Bertubuh Gemuk Pendek. E-Journal Home Economic and Tourism, 8(1). 
Hidayah, N., \& Yasnidawati, Y. (2019). Penyesuaian Pola Dasar Busana Sistem Indonesia Untuk Wanita Indonesia Dengan Bentuk Badan Gemuk. Gorga: Jurnal Seni Rupa, 8(1), 222-230.

Irmayanti, I. (2017). Analisis Perbedaan Fitting Factor antara Pola Sonny dan Pola Praktis pada Jas Wanita. Jurnal MEKOM (Media Komunikasi Pendidikan Kejuruan), 4(2).

Jaya, T. P., \& Suharso, S. (2018). Persepsi Siswa Tentang Faktor yang Mempengaruhi Disiplin Belajar Pada Siswa Kelas XI. Indonesian Journal of Guidance and Counseling: Theory and Application, 7(3), 30-35.

Lestari, D. (2012). Analisis Fitting Factor Pada Vuring Blazer Sistem Soekarno. SKRIPSI Jurusan Tata BusanaFakultas Teknik UM.

Luna, H., \& Iffat, A. (2015). Mahir menjahit tingkat dasar sampai terampil. Klaten: Hafamira.

Rahayu, S. E. P. (2008). Costum 'N Fashion Sejarah dan Teori Busana Dalam Siklus Perkembangan Busana. Malang: FT UM.

Sugiyono, S. (2017). Statistika Untuk Penelitian. Bandung: Alfabeta.

Universitas Negeri Malang. (2017). Pedoman Penulisan Karya Ilmiah. Malang: Universitas Negeri Malang.

Vorensia, S. (2019). Analisis tingkat kenyamanan celana panjang wanita menggunakan pola sistem Porrie Muliawan dan sistem praktis pada ukuran XXL (Doctoral dissertation, Universitas Negeri Malang). 